\title{
CONCEPTION OF LEGAL PROTECTION IN ISLAMIC LAW
}

\author{
Achmad Musyahid Idrus
}

Faculty of Syariah and Law at Alauddin Islamic State University Makassar

\begin{abstract}
Legal protection is an essential requirement for every human being, as one source of law that is recognized an accepted in society and in the country's legal system. Islamic law offers a conception of legal protection oriented towards efforts to bring about worldly and ukhrawi benefits. This study aims to find conceptions of legal protection in Islamic law that are implicitly or explicitly collected in the main sources of Islamic law and the legal thoughts of the mujtahids to then be tested for contextualization in the contemporary era. The method used in this research is normative Islamic law research by making the passage the object of study. The research results obtained in this paper are emphasized that the conception of legal protection in Islam is different from the conception of legal protection that is understood in the legal system in general. The research implication that can be recommended in this study is that Islamic law has a conception of legal protection that is human in nature so it must be explored and developed.
\end{abstract}

Keywords:

Conception; Protection; Islamic Law

\begin{abstract}
Abstrak
Perlindungan hukum merupakan persyaratan penting bagi setiap manusia, sebagai salah satu sumber hukum yang diakui dan diterima di masyarakat dalam sistem hukum negara. Hukum Islam menawarkan konsepsi perlindungan hukum yang berorientasi pada upaya mewujudkan manfaat duniawi dan ukhrawi. Penelitian ini bertujuan untuk menemukan konsepsi perlindungan hukum dalam hukum Islam yang secara implisit atau eksplisit dikumpulkan dalam sumber utama hukum Islam dan pemikiran hukum para mujtahid untuk kemudian diuji kontekstualisasinya di era kontemporer. Metode yang digunakan dalam penelitian ini adalah penelitian hukum Islam normatif dengan menjadikan bagian objek penelitian. Hasil penelitian yang diperoleh bahwa konsepsi perlindungan hukum dalam Islam berbeda dengan konsepsi perlindungan hukum yang dipahami dalam sistem hukum secara umum. Implikasi penelitian yang dapat direkomendasikan dalam penelitian ini adalah bahwa
\end{abstract}


hukum Islam memiliki konsepsi perlindungan hukum yang bersifat manusiawi sehingga harus digali dan dikembangkan.

Kata Kunci:

Konsepsi; Perlindungan; Hukum Islam

\section{A. BACKGROUND}

Tustice is a fundamental principle that becomes the aim of every human being who lives and interacts in a country, but reaching the ideals of the law in a country sometimes experience barriers which arising from law enforcers, thus the jargon of legal protection by the state for society cannot be achieved in one country.

This fact is influenced by, for instance, the lack of understanding among law enforcers on the sociological aspects of the law itself, even though the rule of law is based on the interests of a society. Another fact is that some law enforcers do not implement the rule of law itself, therefore such legal phenomena must be detrimental to society, and in addition there is a tendency that the law made and passed by the legislature is issued with the interests of groups and groups. Facts like this are a form of castration of the law, making it difficult to provide legal protection to the community.

On the other hand, Islamic law as a legal source that is recognized and valid legally in society has an integrative conception with the lives of its adherents in a country, but Islamic law sometimes has difficulty integrating itself into the legal rules of a country formally due to opposition from among the Muslims themselves and those who are afraid and worried about Islamic law. This fact makes the values of humanist Islamic legal protection cannot be realized and realized in people's lives for reasons of concern even though a country still respects the rule of law that lives in society. On that basis, this study will examine the humanist values of Islamic law, specifically those related to the law protection in study of law and conception of Islamic law towards legal protection.

\section{B. THE CONCEPTION OF LAW PROTECTION}

\section{Law Protection in Study of Law}

Legal protection when explained literally can lead to many perceptions and before breaking down the notion of legal protection in the true meaning of legal science, it is necessary to parse a little about the notions that can arise from the use of the term legal protection. Legal protection can mean the protection given to the law so that it is not interpreted differently and not harmed by law enforcement officers and it can also mean the legal protection given by the law to something. Legal protection is a picture of a function that aims to provide justice, order, certainty, usefulness and peace. Legal protection is also understood as a guarantee of government and / or community protection for journalists in carrying out their 
functions, rights, obligations and roles in accordance with the provisions of the applicable laws and regulations. ${ }^{1}$

Philipus Hadjon distinguishes two types of legal protection for the people, namely preventive legal protection and repressive legal protection. The preventive legal protection of the people is given the opportunity to submit objections or opinions before a government decision gets a definitive form. Preventive legal protection is very meaningful for government actions that are based on freedom of action, so the government must be careful in making decisions. ${ }^{2}$

Thus, preventive legal protection aims to prevent disputes. Conversely, repressive legal protection aims to resolve disputes, so that the handling of protection for the people by the general court is included in the category of repressive legal protection. Legal protection for the people is directed at efforts to prevent disputes between the government and the people, resolving disputes between the government and the people by consultation and justice is the last means in an effort to resolve disputes between the government and the people. ${ }^{3}$ Therefore, the legal protection given to the people is an implementation of the principle of recognition and protection of human dignity and dignity. On the other hand, legal protection is always associated with retch state or rule of law because the two concepts cannot be separated from the desire to give recognition to human rights. Therefore, the existence of law in the community is very important, so the law must be built with mental moral constitutionalism that guarantees the freedom and rights of citizens, then obeying the law and the constitution essentially respects human rights because the rule of law basically aims to provide legal protection for the people against various government actions.

The definition of legal protection in the view of legal science only emphasizes the fulfillment of human rights as subjects and objects of law. Therefore, legal protection is understood as a form of service that must be carried out by law enforcement or security personnel to provide security, both physically and mentally to victims and sanctions from threats, harassment, terrorism and violence from any party provided at the investigation, prosecution stage and for examination in a court hearing.

\section{Conception of Law Protection in Islam}

The meaning of the protection of Islamic law can be understood from the contents of various Qur'anic verses, all of which aim to encourage a Muslim to render all his deeds to Allah by seeking protection from Him because He is the best

\footnotetext{
${ }^{1}$ Editorial Team Tatanusa, Kamus Istilah Menurut Peraturan Perundang-Undangan Republik Perdana (Cet. I; Jakarta: Tatanusa, 2008), p. 593.

${ }^{2}$ Philipus Hadjon, Protection for the Indonesian People (Surabaya; PT. Bina Ilmu, 1987), p. 4-5.

${ }^{3}$ With the existence of Law No. 5 of 1986 regarding State Administrative Court, according to Paulus E. Lotung, it does not merely provide harassment of individual rights, but also at the same time protect the rights of the people which give rise to obligations for individuals. Individual rights and obligations must be placed in line, balance and harmony with public interest, based on principle within the nation and state philosophy - Pancasila.
} 
of the protector, as explained in the QS Yusuf / 12; 64, QS al-Ra'd / 13; 11,QS al-Hijr / 15; 17,QS al-Shaffāt / 37: 7:

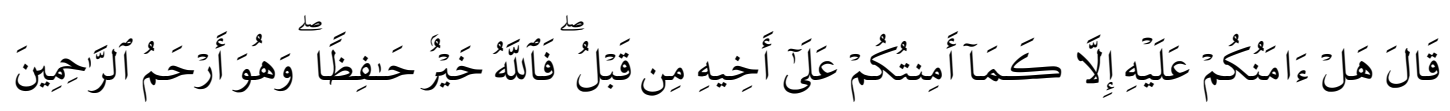

Translation:

Yaqub said: "can I entrust him to you except as I entrusted his brother (Yusuf) to you aforetime? But Allah is the best to guard, and He is the most merciful of those who show mercy.

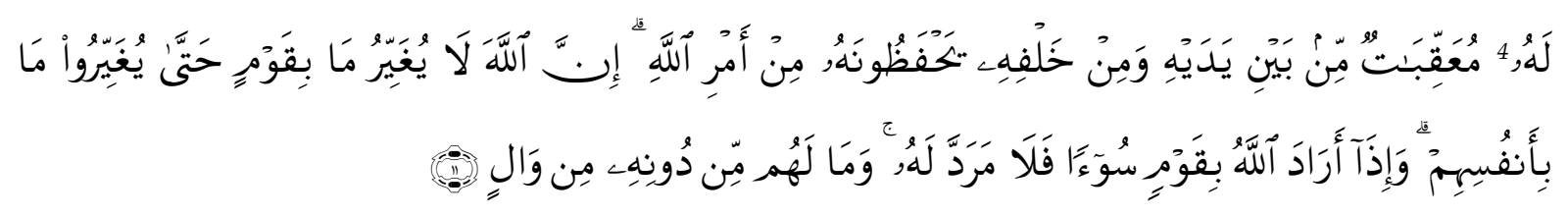

Translation:

For men there are angels who always follow him, in the face and behind them, they keep it by the command of Allah. Verily, Allah does not change the circumstances of a people until they change the circumstances of themselves. Then no one can reject it; and there was never a protector for them except him. ${ }^{5}$

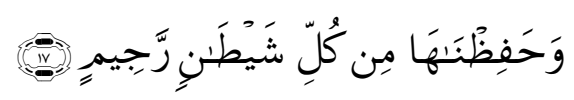

Translation:

And We protect it from every demon that is cursed. ${ }^{6}$

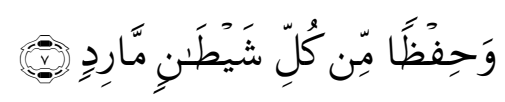

Translation:

And kept it (literally) from every demonic Satan. ${ }^{7}$

The word حَفِ with its various derivatives found in the above verses is used for something that contains the meaning of domination and preservation; The memory of something when it is controlled is called جْفْظ. The strict control of the person to the extent that the person dominates is also called حَفََّ. The mastery of something to be preserved is also called حِفْ Therefore; at least two meanings can be made by scholars

\footnotetext{
${ }^{4}$ It means that Yaqub A.S can not trust Bunyamin to his brothers, because Yusuf was worried that the his previous experience may happen to him. Ministry of Religious Affairs, Alquran dan Terjemahnya, p.193.

${ }^{5}$ For every human being there are some Angels protect them by turns and there are some Angels who record their behavior/action. God will not change their situation, as long as they do not change the reasons for their downfall. Ministry of Religious Affairs, Alquran dan Terjemahny, h.199.

${ }^{6}$ Ministry of Religious Affairs, Alquran dan Terjemahny, p.209.

${ }^{7}$ Ministry of Religious Affairs, Alquran dan Terjemahnya, p.356.
} 
in the sense of this word. First, protection in the sense of preserver. Second, protection in the sense of observing. ${ }^{8}$

Protection in the care of Allah for every person is not only limited to the availability of Allah by the means and infrastructure of life, such as air, water, sun, etc. but more than that. In the teachings of Islam there is what is called sunnatullah and inayatullah. With "natural laws" or habits that occur and are seen in our daily lives. That is why natural laws are an overview of statistical average hours. For example, if there is a plane that exploded in the air or fell down, then we are not surprised if all the passengers were killed, which is called sunnatullah. However, if someone gets inayatullah or the care or protection of Allah like when the plane explodes or crashes he can escapes from the danger of death because of the maintenance or protection. When a person obtains inayatullah (maintenance or protection of Allah), then he will realize that the acquisition is beyond his ability even not reached by his knowledge. ${ }^{9}$ The second meaning of the word supervise", and the verse that talks about the supervision of Allah is found in several verses of the Koran, as contained in QS al-Infithar / 82; 10-12 and QS ath-Thāriq / 86; 4. These two verses have something in common because they both use the word in the redaction of the sentence used, as contained in the following verse, namely;

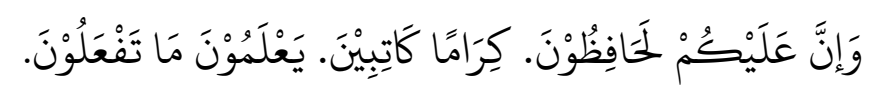

Translation:

Surely there are noble custodians (with Allah) who (function) keep track of your works who know what you are doing. ${ }^{10}$

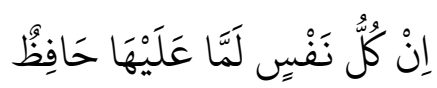

Translation:

There is no soul (self) but there is a preserver. ${ }^{11}$

The use of the word عَلَّ in both verses above sends some scholars to equate the message of Ath-Thāriq with al-Infithār above, namely that each soul has its own guardian who records the deeds of good and bad deeds. These recipients were angels named by the Qur'an by Raqīb and Atīd, as mentioned in the QS Qāf / 26; 16-18.

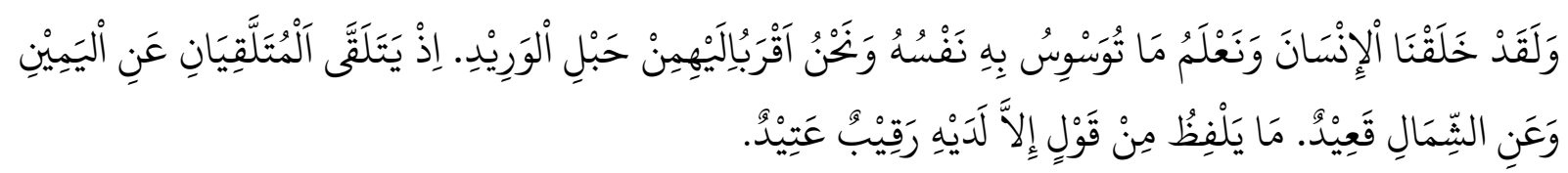

Translation:

And verily we have created man and know what his heart whispers and we are nearer to him

\footnotetext{
${ }^{8}$ M. Quraish Shihab, Tafsir Al-Qur'an Al-Karim, Tafsir Atas Surat-Surat Pendek Berdasarkan Turunnya Wahyu (Cet. 2; Bandung: Pustaka Hidayah, 1997), p. 840.

${ }^{9}$ M. Quraish, Tafsir Al-Qur'an Al-Karim, p. 841.

${ }^{10}$ Ministry of Religious Affairs, Alquran dan Terjemahnya, p. 469.

${ }^{11}$ Ministry of Religious Affairs, Alquran dan Terjemahnya p. 473.
} 
than the veins of his neck. When two Angels recorded their deeds, one sat on the right and the other sat on the left. Not a word was spoken except by the presence of the guardian angel that was always present. ${ }^{12}$

Even though it is difficult for reason to understand their supervision and whereabouts, a Muslim must believe that supervision does exist even though its nature cannot be reached by reason. Feelings of the presence of angels will make every Muslim think before stepping in so as not to be enslaved by lust. The existence of Angels with Raqīb and Atīd is also confirmed in a prophetic hadith which reads as follows;

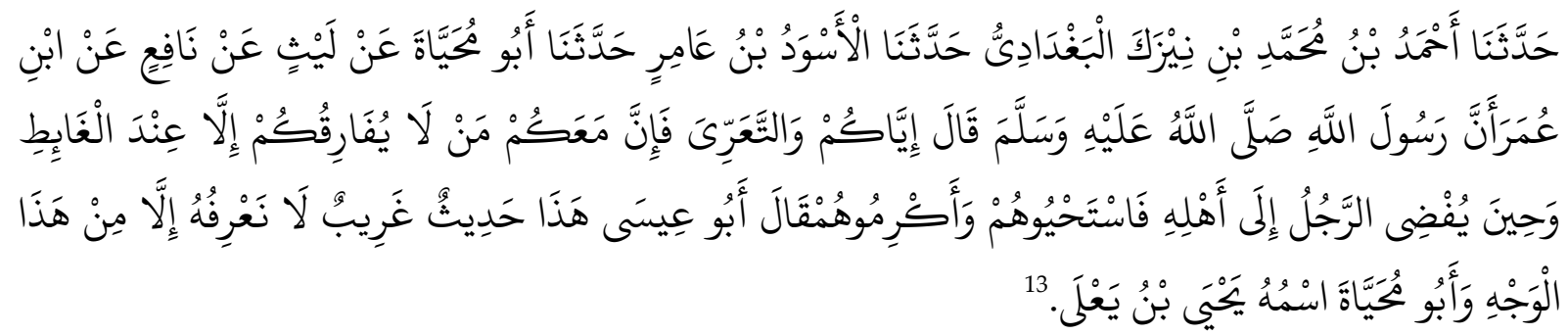

Translation:

Ahmad bin Muhammad bin Nizak Al Baghdadi has told us Al Aswad bin 'Amir has told us Abu Muhayyah of Laits of Nafi' from Ibn Umar that the Prophet shallallahu 'alaihi wasallam said: "Do not be naked (without clothing), because you are always with those (Angels) who are not separated from you, except when you have a big stomach and when a man is having sex with his wife, therefore, shame on them and bless them. "Abu Isa said; This hadith is gharib, we do not know except from this path, whereas Abu Muhayyah is Yahya bin Ya'la. "

According to the above description then the protection of Islamic law is protection against the mukalaf given by Allah as guardian or overseer. Protection in the context of the preserver is to place God as the protector of all kinds of trials that a man undergoes by giving grace, just as the Prophet Joseph experienced when he was seduced by Siti Zulaikha to do acts contrary to the law of God. ${ }^{14}$

The meaning of protection in the case of Prophet Yusuf is a form of Allah's protection to him by giving him His blessing; therefore he realized that lust may lead human to the wrong path. If Yusuf did not receive mercy and protection from Allah Almighty, the prophet would have received and followed Zulaikha's temptation, as explained in Al Quran Chapter/Surah Yusuf 12:53

Translation:

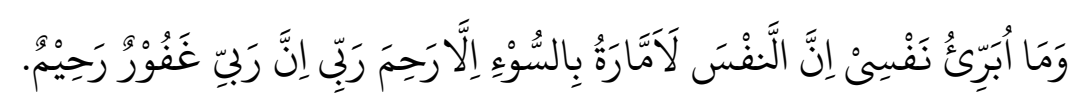

And I do not acquit myself. Indeed, the soul is a persistent enjoiner of evil, except those upon

\footnotetext{
${ }^{12}$ Ministry of Religious Affairs, Alquran dan Terjemahnya p. 414.

${ }^{13}$ Lidwa Pustaka i-Sofware- kitab 9 imam hadis. Sumber: Imam Tirmidzi, Kitab : Adab: Bab Berkain saat jimak, Hadith number 2724.

${ }^{14}$ Ahmad Bahjat, Anbiyā Allah. terj. Muhammad Alkāf, Sejarah Nabi-Nabi Allah (Cet. 2; Jakarta: Lentera, 2006), p. 156-157.
} 
which my Lord has mercy. Indeed, my Lord has mercy. Indeed, my Lord is forgiving and merciful. ${ }^{15}$

According to the author, not all people can obtain the mercy and protection of Allah Almighty, because only certain people can obtain it, a Muslim who can surrender or believe in Him, a Muslim who can do justice because justice is close to being feared and piety is the deepest way to get closer to the protection and preservation of Allah Almighty for those who attain the degree of obedience must find a way out of every problem they face, as outlined in QS ath-Thalaq / 65; 2-3:

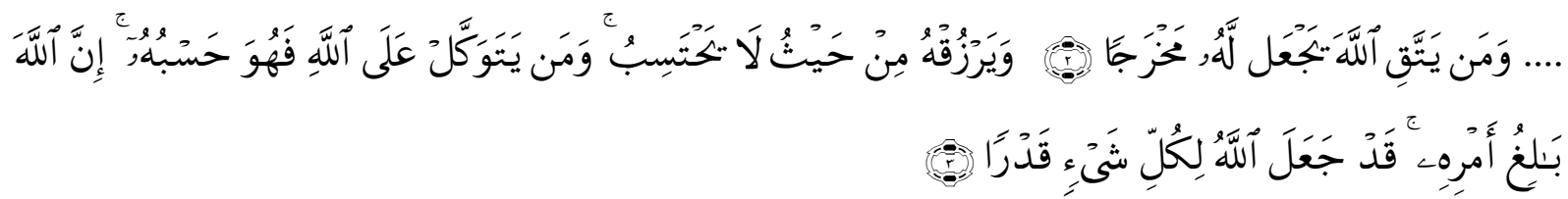

\section{Translation:}

...Whoever fears Allah, He will provide for him a way out. And give him sustenance from an unexpected direction. And whoever trusts in Allah, Allah will suffice. Verily Allah performs His business. Indeed, Allah has made provision for everything. ${ }^{16}$

The question is what the relationship between fear and the solution of each problem as well as the unexpected and sudden blessing. If we pay attention to the above verse, it is understandable that the key to Allah's protection to those who fear Him is by trusting Him. Because by trusting Allah Almighty He will satisfy all human's needs and will take care of everything. Therefore, if there is a person who leaving everything in Allah's hand but still has instable feeling due to many problems of life, it is because they have not yet trusted Allah. ${ }^{17}$

While what is meant by legal protection in the form of supervision is a form of protection given by Allah Almighty to everyone so that the person is protected from the influence of his lust. This is because humans cannot be fully being able to control themselves and take care themselves because in many cases things are in beyond his abilities. It may things that he considered good then proved detrimental to himself. That is why the prophet in one of the traditions ordered everyone to ask for protection from the influence of evil lust, as explained in a hadith which reads as follows:

${ }^{15}$ Ministry of Religious Affairs, Alquran dan Terjemahnya, p. 193.

${ }^{16}$ Ministry of Religious Affairs, Alquran dan Terjemahnya, p. 445.

${ }^{17}$ The privilege of those who are devoted to Allah among others, it is stated in the Qur'an that they are at ease in all matters QS ath-Thalaq/65; 4. Allah makes it easy for him to obtain knowledge QS al-Baqarah/2; 282. Allah will be his/her protector and defender QS al-Jatsiyah/45' 19. Allah will open the door of blessing for him/her membuka pintu keberkehan QS al-A'rāf/7; 96. He/she will be protected from enemy physically and mentally. QS Ali Imrān/3; 120.Allah will save him/her from disaster QS al-Fussilāt/41; 17-18. Allah will protect him/her from bad things QS al-Anfāl/8; 29 . 


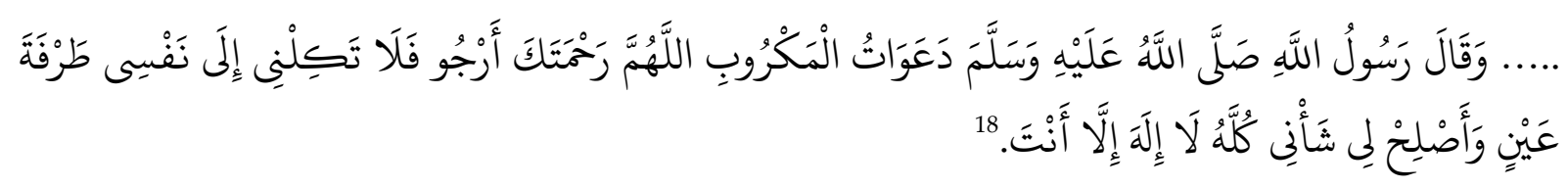

Translation:

... .. "The Prophet sallallaahu 'alaihi wasallam said:" Some prayers for those who are in danger; "ALLAHUMMA RAHMATAKA ARJUU FALAA TAKILNII ILAA NAFSII THARFATA 'AININ WA ASHLIH LII SYA'NII KULLAHU LAA ILAAHA ILLA ANTA (Oh my God my Lord, I expect Your mercy, therefore do not surrender my affairs to myself) eyes, fix all my affairs, there is no God but You.

Although in every human being there is an element of nature or purity, however, everyone is encouraged to seek protection from Allah Almighty from the influence of his/her lust which is blown out by the whisper of the devil. Therefore,

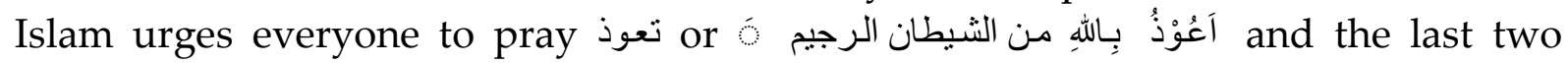
Qur'anic letters are the letters of al-Falaq and al-Nas called a surah of protection (alMuawwizatain). ${ }^{19}$ Both of these are surah used by the Prophet Muhammad to suppress magic traps in knots at a mine launched by an Arabian descent based on the verse in QS al-Nas / 114; 4.

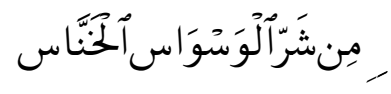

Translation:

From the evil (whispering) evil demons that are used to hide. ${ }^{20}$

While in the prophetic hadith some terms regarding the word protection include نَعَوُْذْ which can mean protection from debt, protection from antichrist,

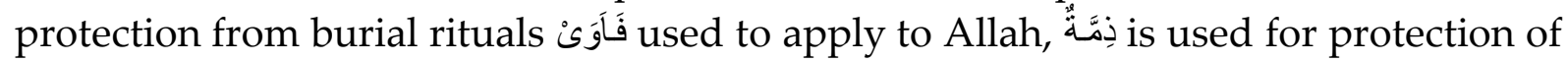
Muslims, protection against debt, protection against war, protection from unbelievers, طِلٌّ protection against the Day of Judgment, حفظ protection against travel and حِى protection against posterity. From these terms, it is understood that the word is a term related to protection against abortion. ${ }^{21}$

In addition, legal protection can be given to anyone who is able to provide it to the person entitled to it, both in the unlawful act and in the context of preventing the person from committing the violation. For example, a married couple who would abort the fetus should be considerate of every other Muslim to prevent such acts, as warned by the prophetic hadith

${ }^{18}$ Lidwa Pustaka i-Sofware- kitab 9 imam hadis.Sumber : Abu Daud, Kitab : Adab, Bab : Doa saat bangun pagi, Hadist Number : 4426

${ }^{19}$ Cyril Glasse, Encyclopedia Islam. Kata Pengantra Prof. Huston Smith.Ter. Ghufron A Mas'adi. Ed. I cet. 2 jakarta: PT. Raja Rafindo Persada, 1999), p.320-321.

${ }^{20}$ Ministry of Religious Affairs, Alquran dan Terjemahnya, p. 485.

${ }^{21}$ See Lidwa Pustaka i-Sofware- kitab 9 imam hadis. 


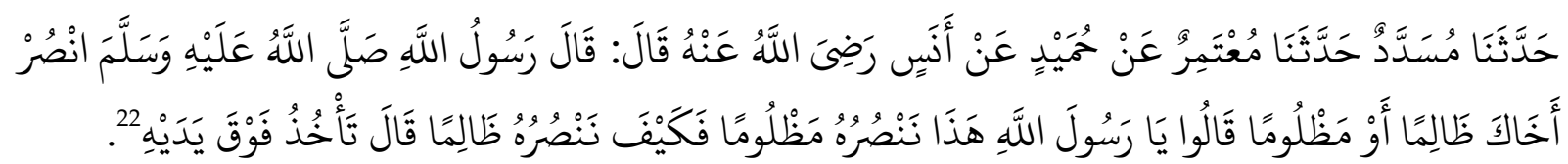

\section{Translation:}

Musaddad has told us Mu'tamir of Humaid from Anas Radliallahu Anhu said; The Messenger of Allah (May peace be upon him) said: 'Help your brother who does zhalim (harm) and those who are being harmed.' Hold his hand (to avoid doing wrong) ". They asked: "O Messenger of Allah, we understand how to help the abused but how should we help the wrongdoer?" He said: "hold his hand (to not doing wrong)."

In the context of a state, legal protection can also be understood as a protection given to the law thus it is not interpreted differently and not harmed by the law enforcement officers and can also mean legal protection given by the law to anything. Here, Islamic law needs to be formalized as national law so that Islamic law is not always understood as something normative, so that it can provide protection against mukalaf and protection of Islamic law itself. ${ }^{23}$

The difference in the understanding of legal protection above is caused by Islamic law is part of the Islamic religious system that makes the Qur'an and Sunnah as a strong source of law, so Islamic law cannot be separated from Allah Almighty as Shari. Therefore, the truth cannot be doubted by anyone where the aim to achieved by Islamic law is justice, truth and order and true welfare. Because Islamic law is related to the faith and other aspects of Islamic teachings, the consequences do not stop at its implementation in the world but relate to human life in the afterlife, so that Islamic law will provide legal consequences that must be accounted for by anyone who does not implement Islamic law. ${ }^{24}$

\footnotetext{
${ }^{22}$ Lidwa Pustaka i-Sofware- kitab 9 imam hadis.Sumber Bukhari, Kitab : Perbuatan-perbuatan zhalim dan merampok. Bab : Tolonglah saudaramu baik yang zhalim atau yang terzhalimi. Nomor.Hadis : 2264.

${ }^{23}$ Therefore, the formalization group of Islamic law viewed that the structural approach will have more binding power, the legitimacy of the law and the power for the implementation of Islamic law are considered more effective against efforts to improve living systems that tend to be destructive today. In addition, Islamic law also has a close relation with people who are based on the assumption that Islamic law has characteristics such as takamul, tasamuh and harakah which are able to maintain their existence in the midst of society. Takamul for example, is a perfect teaching that covers all the basic laws and regulations in human life and can be applied to all level of society in any situation and condition and is able to follow the development of society at any time. While tasamuh is that Islamic law has a high tolerance for the rules which already exists in society. While harakah is that Islamic law has the power to solve every problem and is able to solve it, therefore Islamic law will not be obsolete and out of date. See Abdul Manan, Reformasi Hukum di Indoensia (Cet 1; Jakarta: Raja Grafindo Persada, 2006), p. 94-104. Manusisawi. Bandingkan dengan Abdul Halim, Politik Hukum Islam di Indonesia (Cet. 1; Jakarta: Ciputat Press, 2005), p. 18-25,. See Yusuf Qardhāwi, Madhal li Dirāsah al-Syariah al-Islamimiyah translated by Ade Nurdin and Riswan on the book Membumikan Syari'at Islam ; Keluwesan aturan Ilahi Untuk Manusia (Cet. 1; Bandung; Mizan, 2003), p. 94-160

${ }^{24}$ Law in the Western perspective is something neutral that does not relate directly to a particular religion because law is one of the products of science that is deemed to be free from values that are sourced from religion. Western law is truthfully sourced and produced by the thoughts and thoughts of humans that are full with subjectivity and relative nature. Likewise the justice and truth that it generates are only apparent. Dedi Ismatullah, Sejarah Sosial hukum Islam (Cet. I; Bandung: Pustaka Setia, 2011), p. 49-50.
} 
Based on the above description, then, the protection of Islamic law from the side of qașdu as-syāri is the rule or rule of Islamic law which is principally intended to protect every mukalaf from being freed from its lust. Becoming free from the influence of lust is a gift from God through the earnest efforts of a mukalaf in understanding and fulfilling the divine law (taklif). While the principles of Islam's legal protection from the qasdul mukalaf understands as a set of rules set by the Shari'ah and the rules generated by the reasoning of the mujtahid against the Qur'an and the hadith aimed at protecting the rights of wives and fetuses in relation to abortion the fetus.

Related to this understanding, then as a conception of law that is built on the basis of revelation and developed based on responsible logical reasoning, the purpose of law in Islamic law according to the conclusions of the scholars is to provide protection and guarantee human problems, both in the world and the hereafter. The purpose of Islamic law will be achieved by providing guarantees of basic human rights, in this case the wife and fetus which emphasizes the five main pillars of human life that must be guaranteed and take care of, namely religion, soul, ancestry, reason and property. ${ }^{25}$ All the teachings and rules of law that exist in Islamic law are essentially oriented to guarantee the benefit of human life in which basic human rights are the core of the benefit of human life. And every part of the rule of law that is in Islamic law, both worship, muamalah and fellow human relationships are made to guarantee human rights in different aspects ${ }^{26}$

Therefore, the protection of Islamic law towards human rights can be broadly categorized into two forms, namely; First, the realization of human rights, so that they can be enjoyed by the parties concerned. Second, protecting human rights from various violations caused by the influence of their lust. ${ }^{27}$ These two forms are the manifestation of maintaining the benefit of the five main pillars where the five pillars are stratified according to the level of urgency that starts from darüriyyat, hajjiyāt and tahsiniyyāt. All efforts that directly guarantee or lead to the existence of the five principles are good or maslahah in the darūri level. Therefore God commands humans to make an effort to fulfill these basic needs. Any attempt or action which directly causes the disappearance or destruction of one of the five main elements is bad, therefore God forbids it. Abandoning and avoiding Allah's prohibition is a problem at the dharuri level. ${ }^{28}$

Maslahah hajjiyah is welfare that the level of human life needs but is not at the darūrī level. The form of welfare is not directly for the fulfillment of the five basic needs (dharuri), but indirectly leads towards it as in the case it helps to make it easier

${ }^{25}$ SeeFathi ad-Dharāini, al- Manāhij al-Usuliyah fi Ijtihād bi al-Ra'yi fi al-Tasyrī (Damaskus: Dār alKitāb al-Hadīts, 1975), p. 28.Lihat juga Muhammad Khalid Mas'ūd, Islamic Legal Philosophy (Islamābad Islamic Research Institut, 1977), p. 223.

${ }^{26}$ Suhāil Husāin al-Fathlāwi, Huqūq al-Insān fi al-Islām (Beirūt: Dār al-Fikr al-Arabī, 2001), p. 5.

${ }^{27}$ Muhammad Sa'ad bin Ahmād bin Mas'ūd al-Yūbi, Maqāshid al-Syarīah al-Islāmiyyah wa Alāqatuha fi al-Adillāh al-Syar'iyyah (Cet. I; Riyādh: Dār al-Hijrah, 1418 H/1998), p. 194-209.

${ }^{28}$ Amir Syarifuddin, Ushul Fiqhi. Jilid 2, (Cet. I; Jakarta, Logos Wacana Ilmu, 1999), p. 324. 
for the fulfillment of the needs of human life. Although Maslahah Hajjiyah is also not fulfilled in human life, it also does not directly cause damage to the five main elements, but can indirectly detrimental. Such as studyingreligious knowledge for the establishment of religion, eating for survival, buying and selling to get wealthy. ${ }^{29}$ While Maslahah Tahsiniyyah is the welfare where the needs of human life is not in the level of darūrī, nor to the level of hajjī, but these needs need to be met in order to provide perfection and beauty for human life. Maslahat in the form tahsiniais also related to five basic human needs. ${ }^{30}$

\section{CONCLUSION}

Based on above explanation, the answer for the research problem can be concluded to some key points, which are: The conception of legal protection in Islamic law aims to realize the values of humanity in all aspects of a person's legal actions. The values of humanity contained in the protection of Islamic law are realized in the form of the manifestation of the benefit of humans in the word but to realized the benefit of the hereafter.

\section{RESEARCH IMPLICATION}

Referring to the conclusions above, some entry points that can be recommended in this study are that the values of humanity contained in the conception of legal protection should be further explored and explored so that the values of benefit of Islamic law can be revealed and implemented in human social life.

\section{Bibliografi}

al-Asymawi, Muhammad Said. "Usul asy-Syariah. terj. Luthfi Thomafi. Nalar Kritis Syariah. Edisi Khusus. Cet. I; Yogyakarta: 2012.

ad-Dharāini, Fathi. al- Manāhij al-Usuliyah fi Ijtihād bi al-Ra'yi fi al-Tasyrī. Damaskus: Dār al-Kitāb al-Hadīts, 1975.

al-Fathlāwi, Suhāil Husāin. Huqūq al-Insān fi al-Islām. Beirūt: Dār al-Fikr al-Arabī, 2001.

Ali, Muhammad Daud. Hukum Islam, Pengantar Ilmu Hukum dan Tata Hukum Islam di Indoensia. Edisi Kelima. Cet. 5; Jakarta: Raja Grafindo Persada, 1996.

al-Yūbi, Muhammad Sa'ad bin Ahmād bin Mas'ūd. Maqāshid al-Syarīah al-Islāmiyyah wa Alāqatuha fi al-Adillāh al-Syar'iyyah. Cet. I; Riyādh: Dār al-Hijrah, 1418 $\mathrm{H} / 1998$.

\footnotetext{
${ }^{29}$ Syarifuddin, Ushul Fiqh, p. 328

${ }^{30}$ Syarifuddin, Ushul Fiqh, p.328.
} 
Bahjat, Ahmad. Anbiyā Allah. terj. Muhammad Alkāf, Sejarah Nabi-Nabi Allah. Cet. 2; Jakarta: Lentera, 2006.

Barakatullah, Abdul Halim dan Teguh Prasetyo, Hukum Islam Menjawab Tantangan Zaman yang Terus Berkembang. Cet. I; Yogyakarta: Pustaka Pelajar, 2002.

Glasse, Cyril. Ensiklopedia Islam. Kata Pengantra Prof. Huston Smith.Ter. Ghufron A Mas'adi. Ed. I cet. 2 jakarta: PT. Raja rafindo Persada, 1999.

Hakim, Rahmat. Hukum Pidana Islam. Cet. Ke-2; Bandung: Pustaka Setia, 2010.

Halim, Abdul. Politik Hukum Islam di Indonesia. Cet. 1; Jakarta: Ciputat Press, 2005.

Hadjon, Philipus. Protection for the Indonesian People (Surabaya; PT. Bina Ilmu, 1987),

Ismatullah, Dedi. Sejarah Sosial hukum Islam. Cet. I; Bandung: Pustaka Setia, 2011.

J.N.D. Anderson, Islam Law in the Modern World (New York:New York University Press, 1959.

M. Zein, Satria Effendi. Hukum Islam, Perkembangan dan Pelaksanaannya di Indonesia dalam Ari Anshori (Penyunting) Fikih Indoensia dalam Tantangan (Surakarta: FIAT-UMS, 1991), h. 23.

Manan, Abdul. Reformasi Hukum di Indoensia. Cet 1; Jakarta: Raja Grafindo Persada, 2006.

Mas'ūd, Muhammad Khalid. Islamic Legal Philosophy (Islamābad Islamic Research Institut, 1977.

Qardhāwi, Yusuf. Madhal li Dirāsah al-Syariah al-Islamimiyah diterjemahkan oleh Ade Nurdin dan Riswan dalam Judul membumikan Syari'at Islam ; keluwesan aturan Ilahi untuk manusia. Cet. 1; Bandung; Mizan, 2003.

-------, Studi Kritis as-Sunnah, terj. Bahrun Abu Bakar. Bandung: Trigenda Karya, 1995.

Rochman, M. Ibnu. Hukum Islam dalam Perspektif Filsafat. Cet. 1; Yogyakarta: Philosophy Press, 2011.

Shihab, M. Quraish. Tafsir Al-Qur'an Al-Karim, Tafsir Atas Surat-Surat Pendek Berdasarkan Turunny Wahyu. Cet. 2; Bandung: Pustaka Hidayah, 1997.

Syarifuddin, Amir. Ushul Fiqhi. Jilid 2. Cet. I; Jakarta, Logos Wacana Ilmu, 1999.

Ulwāni, Abdullah Nashih. Syariat Islam Hukum yang Abadi, terj. Daud Rasyid. Jakarta: Usamah Press, 1994. 